\title{
A Rare Case of Multiple Nevoid Hypertrichosis with Atrial Septal Defect
}

\author{
Hyojin Kim, Jong Uk Kim, Gyeong Je Cho, Woo Jung Jin, So Hee Park, Jung Eun Seol \\ Department of Dermatology, Busan Paik Hospital, College of Medicine, Inje University, Busan, Korea
}

\section{Dear Editor:}

An 18-month-old female was evaluated for localized hypertrichosis on the left infraorbital area, left upper back, and dorsal aspect of the left leg (Fig. 1). The lesions were small at birth and had enlarged as she grew up. There was no relevant family history. The patient was born by cesar- ean section at 37 weeks and admitted to the neonatal intensive care unit after birth with a diagnosis of respiratory distress syndrome. Ultrasonography revealed an atrial septal defect that disappeared after 1 year. The patient had normal developmental milestones. A physical examination revealed localized hypertrichosis on the left infraorbital
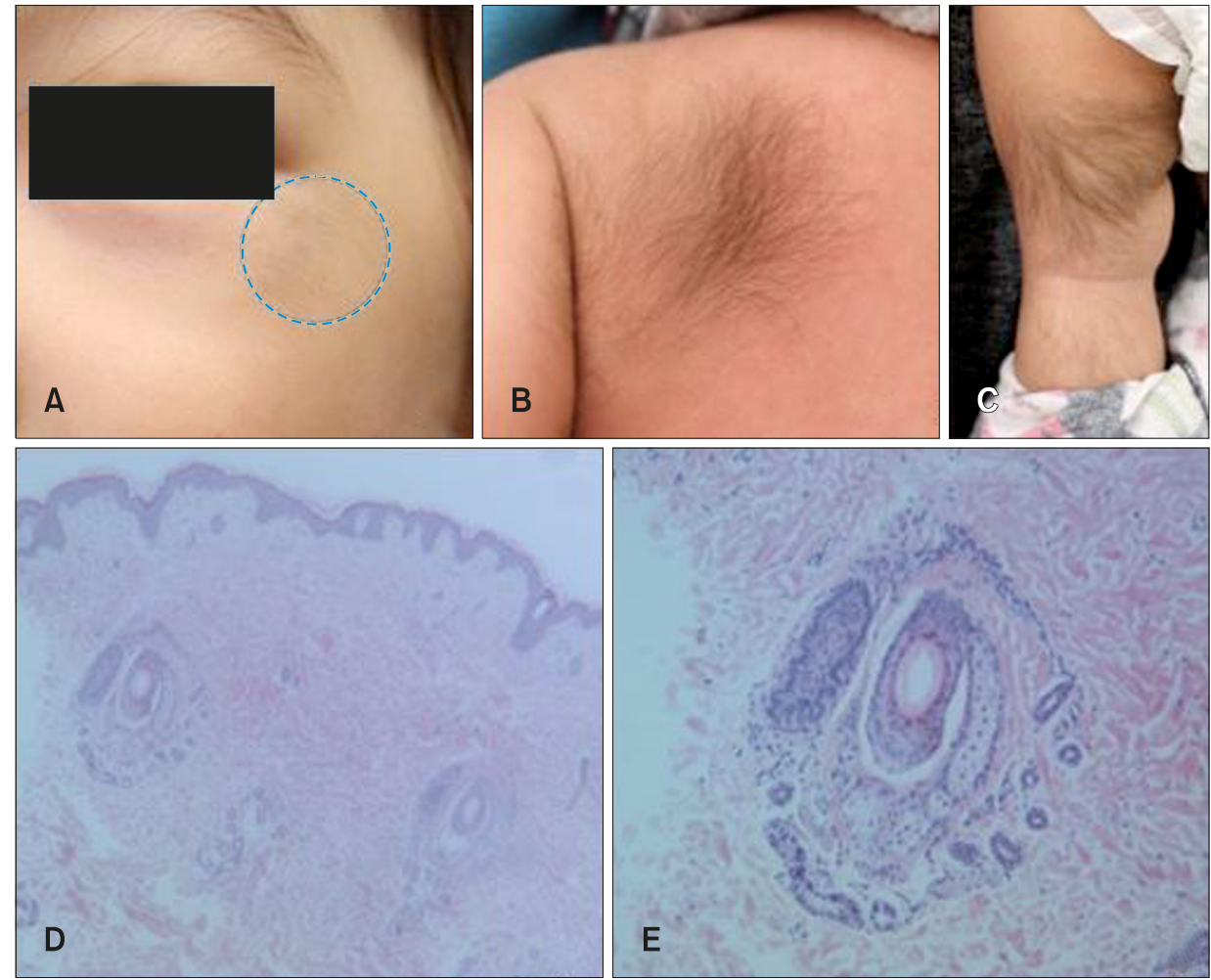

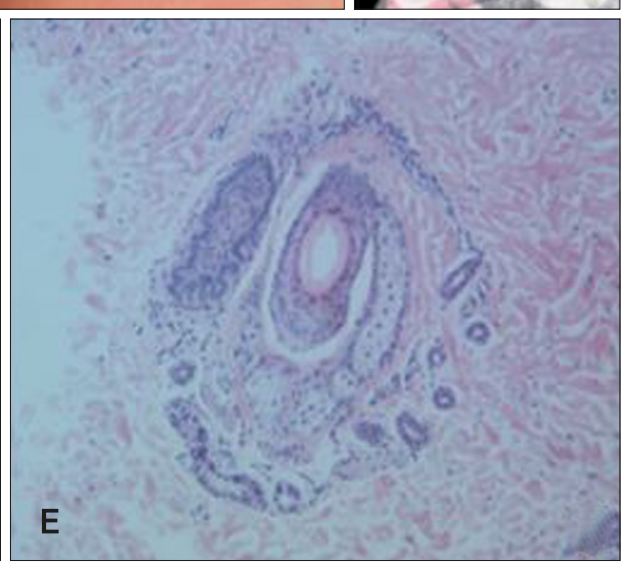

Fig. 1. (A) Localized hypertrichosis on the left periocular area (dotted circle), (B) left upper back, and (C) dorsal aspect of the left leg. Black and coarse terminal hairs about 2 to $3 \mathrm{~cm}$ in length were present on the back and left leg. Slight hypopigmented patches were seen on the left leg. (D) Histology revealed mild acanthosis on the epidermis and mild perivascular inflammation on the upper dermis with terminal hair follicles $(H \& E, \times 40)$. (E) The same findings are shown in a magnified view $(H \& E, \times 100)$. We received the patient's consent form about publishing all photographic materials.

Received July 3, 2019, Revised November 24, 2019, Accepted for publication November 25, 2019

Corresponding author: Jung Eun Seol, Department of Dermatology, Busan Paik Hospital, College of Medicine, Inje University, 75 Bokji-ro, Busanjin-gu, Busan 47392, Korea. Tel: 82-51-890-6135, Fax: 82-51-897-6391, E-mail: derma09@hanmail.net ORCID: https://orcid.org/0000-0002-3029-9635

This is an Open Access article distributed under the terms of the Creative Commons Attribution Non-Commercial License (http://creativecommons.org/licenses/by-nc/4.0) which permits unrestricted non-commercial use, distribution, and reproduction in any medium, provided the original work is properly cited.

Copyright (c) The Korean Dermatological Association and The Korean Society for Investigative Dermatology 
Table 1. Reported cases of multiple nevoid hypertrichosis

\begin{tabular}{|c|c|c|c|c|c|c|c|c|}
\hline Author (year) & $\begin{array}{l}\text { Sex/age } \\
(\mathrm{mo})\end{array}$ & Onset & Ethnicity & Location & Associated disease & $\begin{array}{l}\text { Family } \\
\text { history }\end{array}$ & $\begin{array}{l}\text { Treat- } \\
\text { ment }\end{array}$ & Prognosis \\
\hline Cox et al. $(1989)^{5}$ & Female/6 & At birth & Caucasian & $\begin{array}{l}\text { Upper lips, } \\
\text { both scapulae, } \\
\text { upper arms, buttocks, } \\
\text { Rt. lumber region, } \\
\text { Rt. upper thigh }\end{array}$ & Lipodystrophy & NS & None & Unknown \\
\hline Rogers $(1991)^{6}$ & Female/14 & At birth & Asian & $\begin{array}{l}\text { Trunk, } \\
\text { both extremities }\end{array}$ & $\begin{array}{l}\text { Lipodystrophy, } \\
\text { hypomelanosis of Ito } \\
\text { congenital malrotation } \\
\text { of the gut diaphrag- } \\
\text { matic hernia, } \\
\text { focal iris colobomata, } \\
\text { congenital lung cyst, } \\
\text { polydactyly, } \\
\text { partial anodontia, } \\
\text { malalignment of } \\
\text { some of her teeth }\end{array}$ & NS & None & Unknown \\
\hline $\begin{array}{l}\text { Rupert et al. } \\
(1994)^{7}\end{array}$ & Female/23 & At birth & Caucasian & $\begin{array}{l}\text { Rt. clavicle, } \\
\text { Rt. shoulder, } \\
\text { Rt. upper arm, } \\
\text { buttock both } \\
\text { proximal thigh }\end{array}$ & NS & NS & None & Unknown \\
\hline $\begin{array}{l}\text { Ballmer-Webet } \\
\text { et al. }(1996)^{8}\end{array}$ & Female/16 & At birth & Caucasian & Genitalia, both shins & $\begin{array}{l}\text { Hypomelanosis of Ito, } \\
\text { follicular keratosis, } \\
\text { dysmorphic face, } \\
\text { salmon patch, } \\
\text { dysplastic teeth, } \\
\text { bilateral genu vara, } \\
\text { pes valgus, } \\
\text { hypoplasia of } \\
\text { Lt. buttock, bilateral } \\
\text { hip dislocation }\end{array}$ & NS & None & Unknown \\
\hline $\begin{array}{l}\text { Lestringant } \\
\text { et al. }(1997)^{9}\end{array}$ & Female/21 & At birth & African & $\begin{array}{l}\text { Both cheeks, back, } \\
\text { both extremities }\end{array}$ & $\begin{array}{l}\text { Hypomelanosis of Ito, } \\
\text { dysmorphic face, } \\
\text { digital anomalies, } \\
\text { mental retardation, } \\
\text { partial absence of } \\
\text { corpus callosum }\end{array}$ & NS & None & Unknown \\
\hline $\begin{array}{l}\text { Chang et al. } \\
(1997)^{4}\end{array}$ & Male/21 & $1 \mathrm{yr}$ & Asian & $\begin{array}{l}\text { Chest, Lt. shoulder, } \\
\text { Lt. upper extremity }\end{array}$ & Depigmented skin & NS & None & $\begin{array}{l}\text { Remained } \\
\text { stable for } 3 \mathrm{yr}\end{array}$ \\
\hline $\begin{array}{l}\text { Dudding et al. } \\
(1998)^{1}\end{array}$ & $\begin{array}{l}\text { Female/ } \\
\text { at birth }\end{array}$ & At birth & Asian & $\begin{array}{l}\text { Rt. shoulder, } \\
\text { Rt. upper arm, } \\
\text { Lt. axilla both } \\
\text { buttocks and thighs }\end{array}$ & $\begin{array}{l}\text { Hypomelanosis of Ito, } \\
\text { epidermal nevus, } \\
\text { alopecia, retinal } \\
\text { hyperpigmentation }\end{array}$ & NS & None & $\begin{array}{l}\text { Complete } \\
\text { resolution } \\
\text { after } 2 \mathrm{yr}\end{array}$ \\
\hline $\begin{array}{l}\text { López-Barrantes } \\
\text { et al. }(2002)^{10}\end{array}$ & Female/2 & At birth & Caucasian & $\begin{array}{l}\text { Rt. trunk, Lt. arm, } \\
\text { both legs }\end{array}$ & Hypomelanosis of Ito & NS & None & Unknown \\
\hline $\begin{array}{l}\text { Sotiriadis et al. } \\
(2009)^{2}\end{array}$ & Female/3 & $5 \mathrm{mo}$ & Caucasian & $\begin{array}{l}\text { Lt. scalp, } \\
\text { lumbosacral lesion, } \\
\text { both extremities }\end{array}$ & NS & NS & None & $\begin{array}{l}\text { Remained } \\
\text { stable for } 2 \mathrm{yr}\end{array}$ \\
\hline $\begin{array}{l}\text { Khurana et al. } \\
(2014)^{3}\end{array}$ & Female/3 & At birth & Asian & Both extremities & $\begin{array}{l}\text { Hypomelanosis of Ito, } \\
\text { nail dystrophy }\end{array}$ & NS & None & Unknown \\
\hline Our case & Female/18 & At birth & Asian & $\begin{array}{l}\text { Lt. infraorbital area, } \\
\text { Lt. upper back, } \\
\text { Lt. leg }\end{array}$ & $\begin{array}{l}\text { Hypopigmentation, } \\
\text { atrial septal defect, } \\
\text { clinodactyly }\end{array}$ & NS & None & Unknown \\
\hline
\end{tabular}

Rt.: right, Lt.: left, NS: not significant. 
area, left upper back, and dorsal aspect of the left leg. Black and coarse terminal hairs 2 to $3 \mathrm{~cm}$ in length were present on the patient's back and left leg. Hypopigmented patches were observed on the left leg, but no other skin changes or tumorous lesions were observed. Clinodactyly was noted on the patient's fifth finger. A skin biopsy was performed on the patient's left upper back; histology revealed mild acanthosis and mild folliculocentric inflammation in the upper dermis with terminal hair follicles (Fig. 1). After the biopsy, the patient visited two more times but did not receive any treatment; she has since been lost to follow-up.

Nevoid hypertrichosis is a rare congenital disorder with extraordinary terminal hair growth on normally pigmented skin ${ }^{1}$. The involved hair may be hypopigmented with a rough texture that usually appears as a single lesion and rarely as multiple lesions ${ }^{2}$. Multiple nevoid hypertrichosis refers to nevoid hypertrichosis that occurs at multiple areas. It is predominant in females and presents at or soon after birth ${ }^{1,3}$. The cause is unclear, but concurrence of nevoid hypertrichosis in Gorlin syndrome and Aicardi syndrome resulted in possible relationship with PTCH gene and $\mathrm{X}$ chromosome, which is not clarified yet. Histopathologically, there is no characteristic feature of the disease other than the presence of terminal hairs, as seen in our case. Smooth muscle hamartoma, Becker nevus, and melanocytic nevi which can be presented as focal hypertrichosis should be differentiated and all of them are benign. Ten cases have been reported and some of them were related to accompanying abnormalities (Table 1$)^{1-10}$. It was significant that this case showed concurrent congenital atrial septal defect which was not reported in previous report in addition to cutaneous manifestation and skeletal abnormality ${ }^{1-4,11}$. Moreover, it is noteworthy that majority of affected cases, including our case, have been female; this could be more than a chance association.

In conclusion, the etiology of multiple nevoid hypertrichosis is unknown, but our experience of a case of multiple nevoid hypertrichosis with other cutaneous and systemic findings (especially atrial septal defect) could clarify its origin. Herein, we report a rare case of multiple nevoid hypertrichosis with a literature review.

\section{CONFLICTS OF INTEREST}

The authors have nothing to disclose.

\section{FUNDING SOURCE}

\section{DATA SHARING STATEMENT}

Research data are not shared.

\section{ORCID}

Hyojin Kim, https://orcid.org/0000-0003-0987-4938

Jong Uk Kim, https://orcid.org/0000-0001-8430-0323

Gyeong Je Cho, https://orcid.org/0000-0002-5747-4528

Woo Jung Jin, https://orcid.org/0000-0003-4499-8901

So Hee Park, https://orcid.org/0000-0002-9600-799X

Jung Eun Seol, https://orcid.org/0000-0002-3029-9635

\section{REFERENCES}

1. Dudding TE, Rogers M, Roddick LG, Relic J, Edwards MJ. Nevoid hypertrichosis with multiple patches of hair that underwent almost complete spontaneous resolution. Am J Med Genet 1998;79:195-196.

2. Sotiriadis D, Patsatsi A, Lazaridou E, Sotiriou E, DevliotouPanagiotidou D. Multiple nevoid hypertrichosis as an isolated developmental defect. Pediatr Dermatol 2009;26:436-438.

3. Khurana A, Singal A, Pandhi D. Hypomelanosis of Ito and multiple naevoid hypertrichosis: rare cutaneous mosaicism. Australas J Dermatol 2014;55:e29-e32.

4. Chang SN, Hong CE, Kim DK, Park WH. A case of multiple nevoid hypertrichosis. J Dermatol 1997;24:337-341.

5. Cox NH, McClure JP, Hardie RA. Naevoid hypertrichosis-report of a patient with multiple lesions. Clin Exp Dermatol 1989; 14:62-64.

6. Rogers M. Naevoid hypertrichosis. Clin Exp Dermatol 1991; 16:74.

7. Rupert LS, Bechtel M, Pellegrini A. Nevoid hypertrichosis: multiple patches associated with premature graying of lesional hair. Pediatr Dermatol 1994;11:49-51.

8. Ballmer-Weber BK, Inaebnit D, Brand CU, Braathen LR. Sporadic hypomelanosis of Ito with focal hypertrichosis in a 16-month-old girl. Dermatology 1996;193:63-64.

9. Lestringant GG, Topley J, Sztriha L, Frossard PM. Hypomelanosis of Ito may or may not involve hair growth. Dermatology 1997;195:71-72.

10. López-Barrantes O, Torrelo A, Mediero IG, Zambrano A, Happle R. Nevoid hypertrichosis and hypomelanosis. Eur J Dermatol 2002;12:583-585.

11. Happle R, Kroll P. Nevoid hypertrichosis of the face in a 3-month-old girl with Aicardi syndrome. Eur J Dermatol 2013;23:547-548.

None. 